DOI: https://doi.org/10.24127/ajpm.v8i3.2365

\title{
MODEL STUDENT FACILITATOR AND EXPLAINING TERHADAP KEMAMPUAN PEMAHAMAN KONSEP MATEMATIS
}

\author{
Nindy Citroresmi Prihatiningtyas ${ }^{1}$, Mariyam ${ }^{2}$ \\ ${ }^{1,2}$ Pendidikan Matematika, STKIP Singkawang \\ E-mail: $\quad \frac{\text { nindy.citroresmi@ } \text { gmauil.com }^{1)}}{\text { mariyam.180488@gmail.com }^{2}}$
}

Received 7 October 2019; Received in revised form 6 December 2019; Accepted 28 December 2019

\begin{abstract}
Abstrak
Penelitian ini bertujuan untuk mengetahui pengaruh model Student Facilitator and Explaining terhadap kemampuan pemahaman konsep matematis siswa, keterlaksanaan model Student Facilitator and Explaining, dan aktivitas belajar siswa. Penelitian ini menggunakan desain Quasi Eksperimental. Populasi dalam penelitian ini adalah semua kelas VIII SMP Negeri 6 Singkawang. Sampel diambil dengan teknik cluster random sampling. Adapun sampel yang dipilih terdiri dari dua kelas yaitu kelas VIIIA sebagai kelas eksperimen dan kelas VIIIB sebagai kelas kontrol. Hasil analisis menunjukkan: 1) Adanya perbedaan kemampuan pemahaman konsep matematis siswa antara kelas yang menggunakan model pembelajaran SFE dengan kelas yang menggunakan model pembelajaran langsung; 2) Pengaruh model pembelajaran SFE terhadap kemampuan pemahaman konsep matematis siswa tergolong tinggi; 3 ) Keterlaksanaan model SFE dikategorikan sangat baik; 4) Aktivitas belajar siswa secara keseluruhan sangat aktif.
\end{abstract}

Kata kunci: Aktivitas siswa; kemampuan pemahaman konsep; student facilitator and explaining (SFE)

\begin{abstract}
This study aims to understand the interaction of the Facilitator and Student Explanation (SFE) models to students' mathematical concept understanding abilities, the implementation of the SFE model, and student learning activities.This research is an experimental research design with nonequivalent posttestonly control group design. The population in this study is all class VIII. Samples were taken by cluster random sampling technique. As the selected sample consists of two classes, namely class VIIIA as an experimental class and class VIIIB as a control class. The results of the analysis show:1) There is a difference in the ability to understand students' mathematical concepts between classes using the SFE learning model and classes using the direct learning model;2) The effect of the SFE learning model on students' mathematical concept understanding ability is high;3) The implementation of the SFE model is categorized very well; 4) Student learning activities as a whole are very active.
\end{abstract}

Keywords: Student Facilitator and Explaining (SFE); student activities; understanding of concepts.

\section{PENDAHULUAN}

Kemampuan pemahaman konsep merupakan dasar dan tahapan penting dalam rangkaian pembelajaran matematika. Pemahaman sebuah konsep dalam pendidikan sangat penting karena apabila siswa paham akan sebuah konsep maka akan mempermudah siswa dalam proses belajarnya. Hal ini sejalan dengan salah satu tujuan dari pembelajaran matematika di dalam Peraturan Menteri
Pendidikan Nasional (Permendiknas) Nomor 20 tahun 2006 tentang standar isi yaitu siswa mampu memahami konsep matematika, menjelaskan keterkaitan antar konsep dan mengaplikasikan konsep atau logaritma secara luwes, akurat, efisien, dan tepat dalam pemecahan masalah. Dengan pemahaman siswa dapat mengerti suatu konsep dari materi yang diajarkan. Pemahaman matematika juga merupakan tujuan utama dari setiap 
DOI: https://doi.org/10.24127/ajpm.v8i3.2365

materi yang disampaikan oleh guru untuk mencapai konsep yang diinginkan.

Pentingnya

kemampuan pemahaman konsep matematis juga disampaikan Agustina (2016) yang menyatakan bahwa pemahaman konsep merupakan tipe hasil belajar yang lebih tinggi dari pada pengetahuan. Misalnya dapat menjelaskan dengan susunan kalimatnya sendiri sesuatu yang dibaca atau didengarnya, memberikan contoh lain dari yang telah dicontohkan, atau menggunakan petunjuk penerapan pada kasus lain. Matematika tidak ada artinya kalau hanya dihafalkan. Hal tersebut sejalan dengan pendapat Marthafera,dkk (2017) pemahaman konsep adalah kemampuan seseorang dalam mengonstruksi suatu konsep yang ada berdasarkan pengetahuan dasar yang dimiliki dengan menggunakan kata-kata sendiri dan mampu membuat hubungan dengan pengetahuan yang baru. Lebih lanjut Ningsih (2017) mengatakan pemahaman konsep merupakan landasan penting bagi siswa untuk berpikir dalam menyelesaikan permasalahan, sehingga dalam pembelajaran matematika memang dituntut untuk dapat memfasilitasi kemampuan pemahaman konsep agar siswa dapat menyelesaikan semua permasalahan yang diberikan kepadanya.

Namun kenyataan dilapangan menunjukkan bahwa kemampuan pemahaman kosep matematis siswa masih rendah dalam proses pembelajaran. Hal tersebut diperkuat dari hasil penelitian yang dilakukan oleh Purwaningsih (2015) yang berjumlah 22 siswa, ditemukan adanya permasalahan pada pemahaman konsep matematika siswa. Sedangkan hasil penelitian Isrotun (2014) sebanyak 41 orang yang terdiri dari 20 siswa lakilaki dan 21 siswa perempuan, diketahui bahwa pemahaman konsep matematika selama ini masih rendah.

Selain itu berdasarkan dari studi pendahuluan yang dilakukan di SMP Negeri 6 Singkawang dengan memberikan soal yang mengandung indikator kemampuan pemahaman konsep didapat bahwa sebagian besar siswa masih belum mampu mengerjakan soal tersebut hal ini mengindikasikan bahwa pemahan konsep siswa masih rendah. Tidak hanya pemahaman konsep, penulis juga mengobservasi aktivitas belajar siswa selama proses pembelajaran matematika. Dari observasi tersebut dapat disimpulkan bahwa selama pembelajaran di kelas aktivitas siswa masih tergolong rendah. Rendahnya aktivitas siswa tersebut terlihat dari kurangnya pertanyaan siswa pada materi yang kurang dipahami dan saat guru memberikan pertanyaan kepada siswa mengenai materi yang sedang dipelajari, siswa cenderung pasif. Hal ini di dukung pula oleh pernyataan Rahmayanti (2014) dalam penelitiannya dalam pembelajaran matematika siswa masih pasif, takut dan malu untuk bertanya, siswa memilih untuk diam jika ada hal yang belum mereka pahami dari pada harus bertanya kepada guru yang mengajar.

Salah satu upaya untuk mengatasi permasalahan diatas adalah perlu dilakukan sebuah tindakan berupa pemberian model pembelajaran matematika yang sesuai dengan karakteristik siswa yang memungkinkan pemahaman siswa akan lebih cepat dan akhirnya dapat meningkatkan kemampuan pemahaman konsep matematis siswa. Dalam matematika terdapat sebuah model pembelajaran yaitu Student Facilitator 
and Explaining. Menurut Purnitawati (2011) model pembelajaran Student Facilitator and Explaining merupakan salah satu model pembelajaran inovatif dimana dalam model pembelajaran ini siswa/peserta didik belajar mempresentasikan ide atau pendapat pada rekan peserta didik lainnya. Model pembelajaran Student Facilitator and Explaining ini akan dapat berjalan sesuai dengan yang diharapkap apabila siswa secara aktif ikut serta dalam merancang materi pembelajaran yang akan dipresentasikan. Hal ini sejalan dengan pendapat Yanto \& Juwita (2018) yaitu model pembelajaran Student Facilitator and Explaining menekankan siswa untuk berpartisipasi aktif dalam proses pembelajaran dengan memberikan kesempatan siswa yang ditunjuk untuk menjelaskan materi pelajaran yang telah dijelaskan guru kepada siswa lainnya. Dengan demikian siswa akan lebih dapat mengerti dan mampu memahami konsep untuk mengungkapkan pendapat. Selain itu, guru juga dapat mengajak siswa secara mandiri mengembangkan potensi dalam mengungkapkan ide atau gagasan.

Berdasarkan uraian di atas, tujuan penelitian ini adalah untuk melihat pengaruh model Student Facilitator anf Explainning (SFE) terhadap kemampuan pemahaman konsep matematis siswa. Secara lebih rinci tujuan penelitian ini adalah; 1) untuk melihat perbedaan kemampuan pemahaman konsep matematis siswa antara yang menggunakan model pembelajaran SFE dan dengan menggunakan model pembelajaran langsung; 2) untuk melihat seberapa besar pengaruh model SFE terhadap kemampuan pemahaman konsep matematis siswa; 3) untuk melihat keterlaksanaan model SFE terhadap kemampuan pemahaman konsep matematis siswa, dan 4) untuk melihat aktivitas siswa terhadap model pembelajaran SFE.

\section{METODE PENELITIAN}

Jenis penelitian ini adalah jenis penelitian kuantitatif dengan metode eksperimen. Desain penelitian yang digunakan dalam penelitian ini adalah quasi-eksperimental design dengan rancangan nonequivalent posttest-only control group design. Terdapat dua kelas dalam penelitian ini yaitu kelas pertama disebut sebagai kelas eksperimen dan kelas kedua disebut sebagai kelas kontrol. Adapun sekolah yang menjadi tempat penelitian adalah di SMP Negeri 6 Singkawang kelas VIII. Populasi dalam penelitian ini adalah seluruh kelas VIII SMP Negeri 6 Singkawang yang terdiri dari 5 kelas yang berjumlah 160 orang. Teknik pengambilan sampel pada penelitian ini dengan menggunakan teknik cluster random sampling. Adapun yang menjadi kelas eksperimen adalah kelas VIIIA dan kelas kontrol adalah kelas VIIIB, yang masing-masing berjumlah 32 orang.

Teknik analisis data yang digunakan dalam penelitian ini adalah analisis kuantitatif dengan statistika. Setelah data penelitian terkumpul dari hasil pengumpulan data melalui tes dan lembar lembar observasi, kemudian diolah sesuai langkah-langkah sebagai berikut; untuk melihat perbedaan kemampuan pemahaman konsep matematis siswa antara pembelajaran dengan model SFE dan model pembelajaran langsung menggunakan uji normalitas, uji homogenitas dan uji t-test ; untuk mengetahui seberapa besar pengaruh model pembelajaran 
DOI: https://doi.org/10.24127/ajpm.v8i3.2365

SFE dilakukan perhitungan dengan Effect Size; untuk keterlaksanaan dan aktivitas siswa akan dilihat dari lembar observasi keterlaksanaan dan aktivitas yang selanjutnya diukur dengan skala likert.

\section{HASIL PENELITIAN DAN PEMBAHASAN}

\section{Kemampuan Pemahaman Konsep Matematis Siswa}

Hasil pengumpulan data selama penelitian diperoleh data hasil posttest (berupa skor) dari kelas yang diajarkan dengan model pembelajaran Student
Facilitator and Explaining (SFE) untuk kelas eksperimen dan pembelajaran langsung untuk kelas kontrol terhadap kemampuan pemahaman konsep matematis siswa pada materi relasi dan fungsi. Penilaian kemampuan pemahaman konsep matematis siswa dinilai dari skor rata-rata kemampuan pemahaman konsep matematis siswa. Adapun indikator dalam penelitian ini antara lain: (a) Menyatakan ulang sebuah konsep; (b) Memberi contoh dan non-contoh dari sebuah konsep; (c) Mengaplikasikan konsep atau algoritma pemecahan masalah

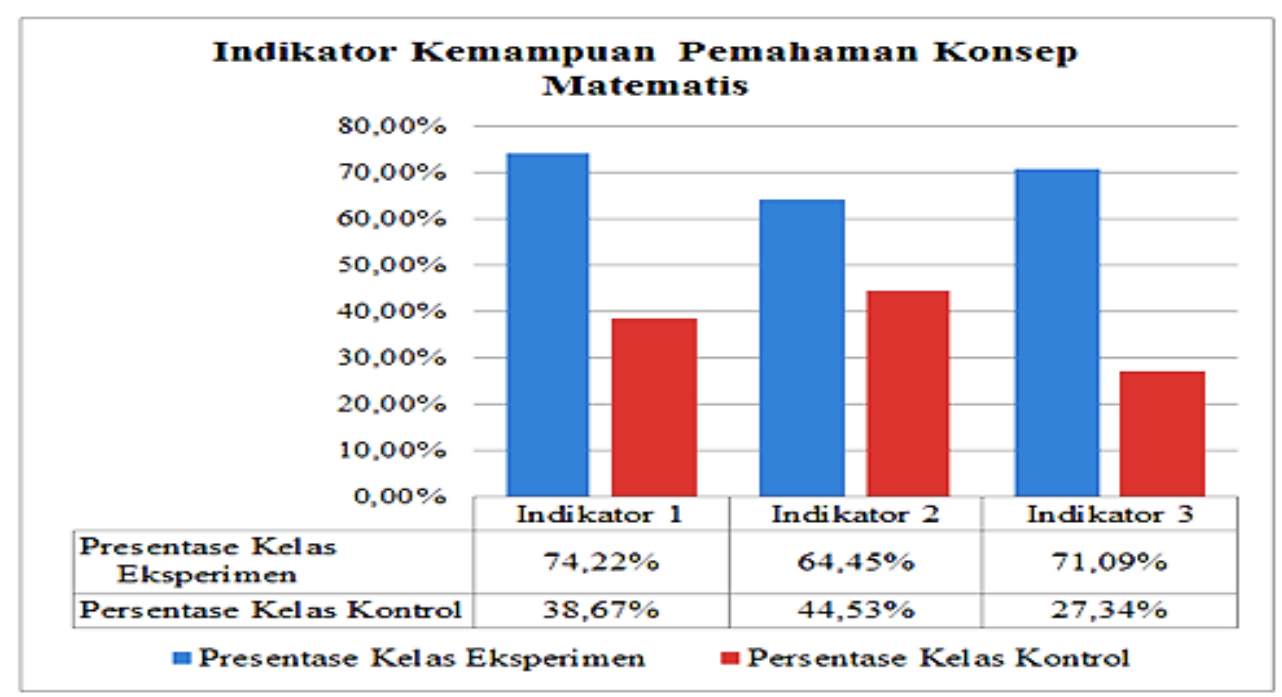

Gambar 1. Diagram Persentase kemampuan pemahaman konsep matematis siswa kelas eksperimen dan kelas kontrol.

Dari Gambar 1 diketahui bahwa
rata-rata indikator kemampuan
pemahaman konsep matematis siswa
kelas eksperimen lebih tinggi daripada
rata-rata indikator kemampuan
pemahaman konsep matematis siswa
kelas kontrol. Selanjutnya secara
keseluruhan rata-rata hasil posttest

kemampuan pemahaman konsep siswa kelas eksperimen dan kelas kontrol dapat dilihat pada Gambar 2. 
DOI: https://doi.org/10.24127/ajpm.v8i3.2365

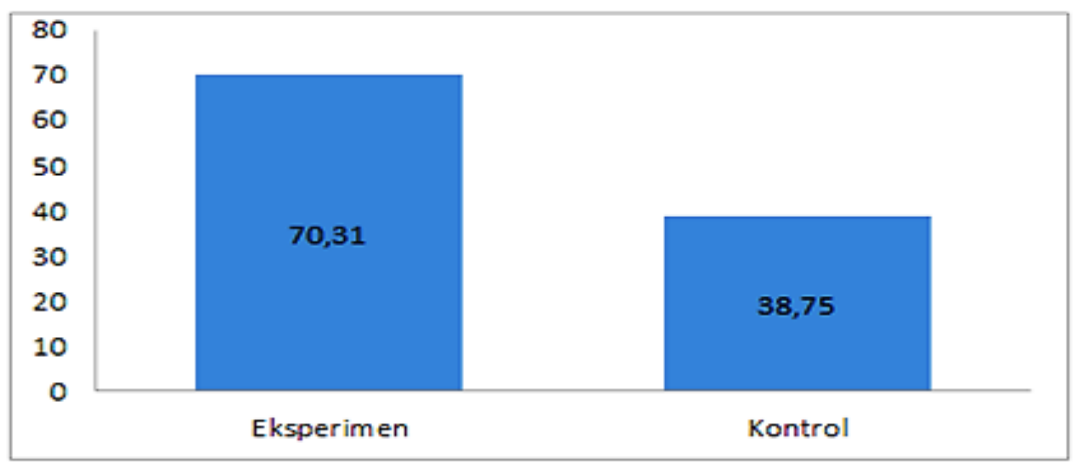

Gambar 2. Diagram batang nilai rata-rata hasil posttest kelas eksperimen dan kelas kontrol.

Dari Gambar 1 dan 2 menunjukkan bahwa secara deskriptif rata-rata posttest antara kelas kontrol dan kelas eksperimen berbeda, namun secara inferensial nilai tersebut belum tentu memiliki perbedaan yang signifikan Untuk melihat perbedaan antara kelas yang menggunakan model pembelajaran Student Facilitator and Explaining (SFE) dengan kelas yang menggunakan model pembelajaran langsung (kelas kontrol) maka menggunakan uji-t dua sampel independen. Namun sebelumnya dilakukan uji normalitas dan uji homogenitas. Berdasarkan hasil perhitungan, untuk data posttest kelas eksperimen dan kontrol disajikan ada Tabel 1.

Tabel 1. Rekapitulasi perhitungan uji normalitas kelas eksperimen dan control.

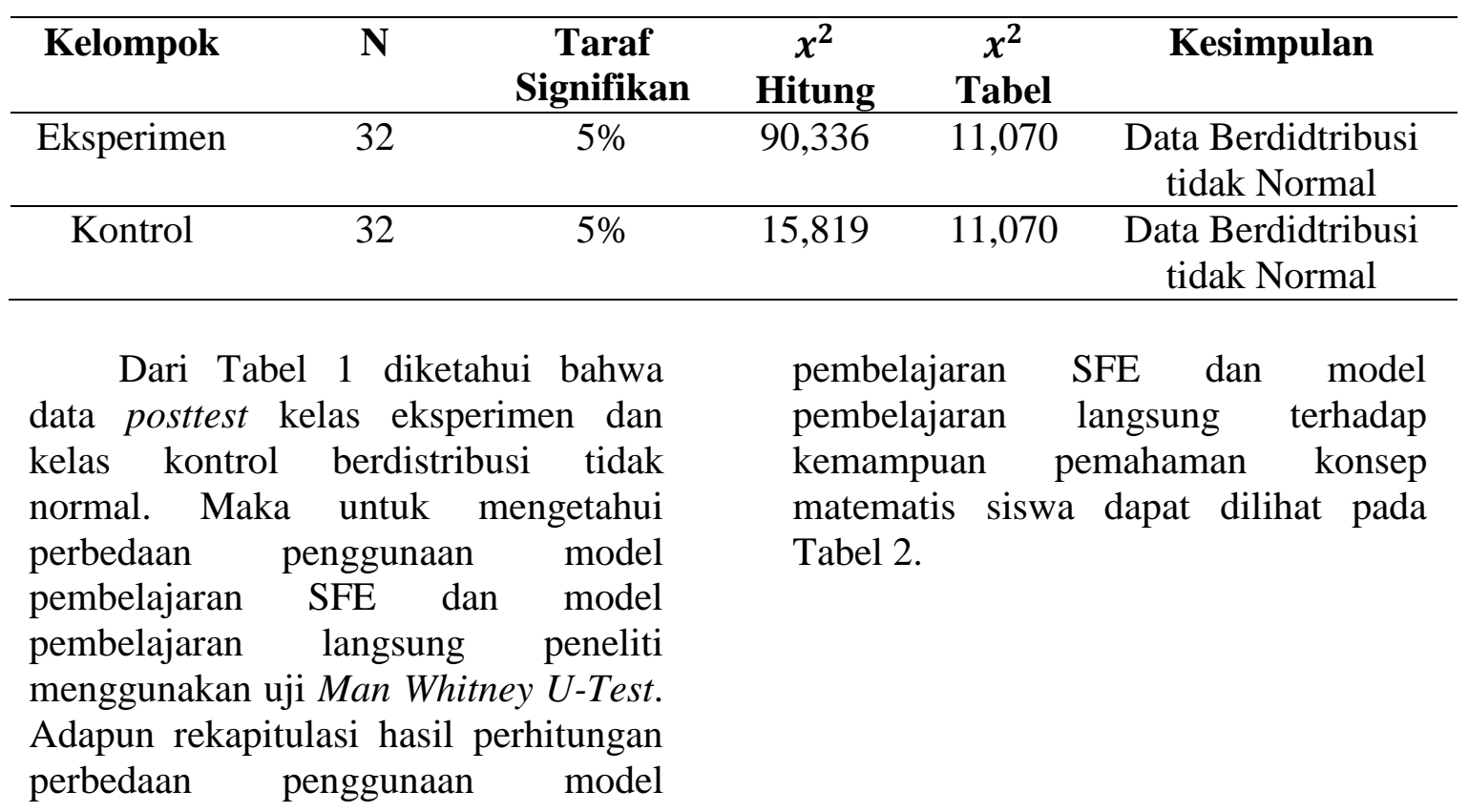


DOI: https://doi.org/10.24127/ajpm.v8i3.2365

Tabel 2 Rekapitulasi perhitungan uji Man Whitney U-test

\begin{tabular}{ccccccc}
\hline Keterangan & $\boldsymbol{n}_{\mathbf{1}}$ & $\boldsymbol{n}_{\mathbf{2}}$ & $\boldsymbol{U}_{\mathbf{1}}$ & $\boldsymbol{U}_{\mathbf{2}}$ & $\boldsymbol{E}(\boldsymbol{U})$ & $\operatorname{Var}(\boldsymbol{U})$ \\
\hline Skor & 32 & 32 & 50,5 & 973,5 & 104,25 & 1811,25 \\
$\boldsymbol{Z}_{\text {hitung }}$ & & & & $-6,20$ & & \\
$-\boldsymbol{Z}_{\text {tabel }}$ & & & & $-1,96$ & & \\
\hline
\end{tabular}

Dari Tabel 2 terlihat bahwa nilai $Z_{\text {hitung }}=-6,20$. Berdasarkan kriteria pengujian maka penggunaan model pembelajaran SFE dan model pembelajaran langsung terhadap kemampuan pemahaman konsep matematis siswa dikatakan memiliki perbedaan apabila $Z_{\text {hitung }}<-Z_{\text {tabel }}$ atau $\mathrm{H}_{\mathrm{o}}$ ditolak, sebaliknya dikatakan tidak ada perbedaan penggunaan model pembelajaran SFE dan model pembelajaran langsung terhadap kemampuan pemahaman konsep matematis siswa apabila $-Z_{\text {tabel }} \leq Z_{\text {hitung }}$ $\leq \mathrm{Z}_{\text {tabel }}$ atau $\mathrm{H}_{\mathrm{o}}$ diterima. Diketahui $\mathrm{Z}_{\text {hitung }}<-\mathrm{Z}_{\text {tabel }}$ atau $-6,20<-1,96$, maka
Ho ditolak. Dapat disimpulkan bahwa terdapat perbedaan penggunaan model pembelajaran Student Facilitator and Explaining dan model pembelajaran langsung terhadap kemampuan pemahaman konsep matematis siswa pada materi relasi dan fungsi kelas VIII SMP Negeri 6 Singkawang.

Selanjutnya untuk melihat seberapa besar pengaruh model pembelajaran SFE terhadap kemampuan pemahaman konsep matematis siswa, maka digunakan rumus Effect Size. Adapun hasil perhitungan Effect Size dapat dilihat pada Tabel 3.

Tabel 3 Rekapitulasi hasil uji Effect Size

\begin{tabular}{ccccc}
\hline Kelas & Nilai Rata-rata & $\begin{array}{c}\text { Standar Deviasi } \\
\text { Kelas Kontrol }\end{array}$ & Effect Size $($ ES) & Kriteria \\
\hline $\begin{array}{c}\text { Eksperimen } \\
\text { Kontrol }\end{array}$ & 70,31 & 13,85 & 2,28 & $\begin{array}{c}\text { Pengaruhnya } \\
\text { Tinggi }\end{array}$ \\
\hline
\end{tabular}

Dari Tabel 3 dapat dilihat bahwa hasil perhitungan Effect Size $=2,28$ dengan kriteria tinggi karena 2,28 berada pada $\mathrm{ES} \geq 0,8$. Ini berarti model pembelajaran Student Facilitator and Explaining memberikan pengaruh terhadap kemampuan pemahaman konsep matematis siswa yaitu sebesar 2,28 yang masuk pada kriteria tinggi. Hal ini sejalan dengan hasil penelitian Darwis,dkk (2014) bahwa hasil analisis dan pembahasan terhadap uji hipotesis yang dilaksanakan pada kelas VII di MTs Negeri Pasir Lawas, terlihat adanya perbedaan nilai rata-rata antara kelas eksperimen dan kelas kontrol. Dilihat dari hasil perhitungan uji-t dengan nilai rata-rata kemampuan pemahaman konsep matematis siswa kelas eksperimen lebih tinggi yaitu 78,57 sedangkan nilai rata-rata kelas kontrol yaitu 69,76. Selain itu Mulyani (2016) dalam penelitiannya juga mengemukakan bahwa model pembelajaran Student Facilitator and Explaining memberikan pengaruh positif terhadap pemahaman matematis siswa. Hal ini membuktikan bahwa pemahaman konsep matematika siswa dengan penerapan model pembelajaran Student Facilitator and Explaining lebih baik dari pada pemahaman konsep matematika siswa dengan pembelajaran dengan model langsung. 


\section{Keterlaksanaan Model Student Facilitator and Explaining (SFE)}

Lembar observasi keterlaksanaan yang dlakukan dalam penelitian ini adalah untuk mengetahui keterlaksanaan pembelajaran dengan menggunakan model Student Facilitator and Explaining (SFE) pada materi relasi dan fungsi. Observasi yang dilakukan dengan menggunakan lembar observasi yang telah disusun, dimana semua indikator yang diobservasi dalam penelitian ini dikembangkan dari setiap langkahlangkah pembelajaran model Student Facilitator and Explaining (SFE) yang dilakukan sebanyak dua kali pertemuan yang dilakukan oleh 2 orang observer yaitu satu guru dan satu mahasiswa. Adapun hasil analisis penelitian data lembar keterlaksanaan model Student Facilitator and Explaining (SFE) sebagai berikut; pengamatan keterlaksanaan pada pertemuan pertama yang memuat dua puluh lima kegiatan memperoleh persentase sebesar 91,20\%, sedangkan pada pertemuan kedua yang memuat dua puluh lima kegiatan memperoleh persentase sebesar 95,00\%. Kemudian melihat persentase rata-rata dari dua kali pertemuan yang memperoleh persentase sebesar 93,20\%, maka keterlaksanaan model pembelajaran Student Facilitator and Explaining dikategorikan sangat baik.

Sejalan dengan penelitian Sujuni, Jamal, \& Suyidno (2014) yang menyimpulkan bahwa Keterlaksanaan RPP model pembelajaran kooperatif tipe Student Facilitator and Explaining meningkat pada setiap siklusnya, dimana pada siklus I sebesar 79,7\% (baik), pada siklus II sebesar 83,6\% (sangat baik), dan pada siklus III sebesar $89,8 \%$ (sangat baik). Hal ini menunjukkan bahwa keterlaksanaan
RPP mencapai indikator keberhasilan yaitu minimal baik.

\section{Aktivitas Belajar Siswa}

Lembar observasi digunakan untuk mengetahui aktivitas siswa selama mengikuti pembelajaran dengan menggunakan model pembelajaran Student Facilitator and Explaining. Pengamatan yang dilakukan selama dua kali pertemuan yang dilakukan oleh 3 orang pengamat, secara ringkas dinyatakan sebagai berikut; data persentase aktivitas siswa diperoleh rata-rata dari empat kategori pengamatan, dua kali pertemuan dan tiga orang pengamat yaitu sebesar $88,47 \%$. Hal ini menunjukkan bahwa aktivitas siswa selama pembelajaran berlangsung berada pada kategori sangat aktif. Dengan demikian dapat disimpulkan bahwa aktivitas siswa tergolong aktif pada pembelajaran materi relasi dan fungsi dengan menggunakan model pembelajaran Student Facilitator and Explaining.

Sejalan dengan penelitian Sujuni, Jamal, \& Suyidno (2014) yang menyimpulkan bahwa aktivitas siswa dalam mengikuti pembelajaran kooperatif tipe Student Facilitator and Explaining Pada siklus I semua aspek sudah berkategori aktif kecuali aspek menjawab pertanyaan dan menjelaskan kepada teman, pada siklus II semuanya sudah berkategori minimal aktif kecuali menjawab pertanyaan, dan pada siklus III semua aspek sudah berkategori minimal aktif. Hal tersebut sesuai dengan yang dikatakan oleh Widyawati (2016) dalam penelitiannya bahwa model Pembelajaran SFE melatih keaktifan dan keberanian siswa dalam mempersentasikan materi yang akan dibahas dalam pembelajaran Secara keseluruhan aktivitas siswa saat mengikuti pembelajaran kooperatif tipe 
DOI: https://doi.org/10.24127/ajpm.v8i3.2365

Student Facilitator and Explaining meningkat dari kategori aktif menjadi sangat aktif.

\section{KESIMPULAN DAN SARAN}

Berdasarkan hasil penelitian dan pembahasan dapat disimpulkan bahwa model pembelajaran Student Facilitator and Explaining (SFE) dapat memberikan pengaruh yang tinggi terhadap kemampuan pemahaman konsep matematis pada materi relasi dan fungsi kelas VIII SMP Negeri 6 Singkawang. Sesuai dengan sub-sub rumusan masalah penelitian, secara khusus dapat disimpulkan bahwa 1) Terdapat perbedaan kemampuan pemahaman konsep matematis antara siswa yang mendapatkan model pembelajaran SFE dengan siswa yang mendapatkan model pembelajaran langsung. 2) Model pembelajaran SFE memberikan pengaruh terhadap kemampuan pemahaman konsep matematis siswa. 3) Keterlaksanaan model pembelajaran SFE tergolong sangat baik terhadap kemampuan pemahaman konsep matematis siswa. 4) Aktivitas belajar siswa dengan menggunakan model pembelajaran SFE pada materi relasi dan fungsi tergolong pada kriteria aktif.

Untuk peneliti selanjutnya, diharapakan dapat menerapkan Model SFE untuk melihat atau mengukur kemampuan matematis lainnya dalam pembelajaran matematika tidak hanya terhenti pada satu kemampuan saja.

\section{DAFTAR PUSTAKA}

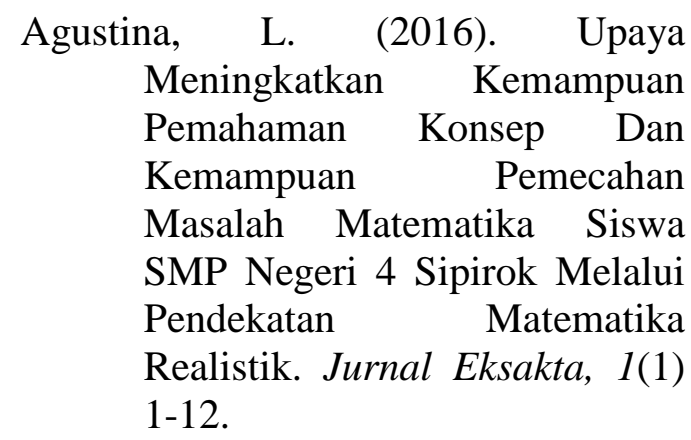

Darwis, A., Maris, I. M., \& Zulmardi. (2014). Penerapan Model Pembelajaran Student Facilitator and Explaining Terhadap Kemampuan Pemahaman Konsep Matematika Siswa Kelas VII Mtsn Pasir Lawas. Jurnal Pendidikan MIPA, 1(1), 77-78.

Isrotun, U. (2014). Peningkatan Pemahaman Konsep

Matematika Melalui Penerapan Pembelajaran Realistik (PTK Pada Siswa Kelas VIIIH Semester Genap MTs Negeri Surakarta II Tahun Ajaran 2013/2014). Doctoral dissertation. Universitas Muhammadiyah Surakarta.

Marthafera, P., Melati, H. A., \& Hadi, L. (2017). Deskripsi Pemahaman Konsep Siswa Pada Materi Laju Reaksi. Jurnal FKIP Untan Pontianak, 7(1), 1-9.

Mulyani, E. (2016). Pengaruh Penggunaan Model Pembelajaran Kooperatif tipe Student Facilitator and Explaining terhadap Pemahaman Matematik Peserta Didik. Jurnal Penelitian dan Pengajaran Matematika, 2(1) 29-34. 
DOI: https://doi.org/10.24127/ajpm.v8i3.2365

Ningsih, S. Y. (2017). Peningkatan Kemampuan Pemahaman Konsep Siswa Melalui Pendekatan Tematik Realistik di SMP Swasta Tarbiyah Islamiyah. Journal of Mathematics Education and Science, 3(1), 82-90.

Permendiknas. (2006). Peraturan Menteri Pendidikan Nasional Republik Indonesia Nomor 20 Tahun 2006 Tentang Standar Isi Sekolah Menengah Pertama. Jakarta: BSNP

Purnitawati, D. (2011). Penerapan Model Student Facilitator and Explaining dengan Menggunakan Metode Eksperimen Untuk Meningkatkan Motivasi dan Hasil Belajar IPA Pada Siswa Kelas IV di SD No 1 Beratan Tahun Pelajaran 2011/2012. Skripsi. Universitas Pendidikan Ganesha.

Purwaningsih, A. (2015). Peningkatan Pemahaman Konsep Pembelajaran Matematika Melalui Pendekatan Reciprocal Teaching Kelas VII Semester Gasal SMP Muhammadiyah 10 Surakarta Tahun Ajaran 2015/2016. Skripsi. Universitas Muhammadiyah Surakarta.

Rahmayanti, D. (2014). Perbandingan Kemampuan Komunikasi Matematik siswa antara yang Mendapatkan Model Pembelajaran Student Facilitator and Explaining dengan Konvensional. Jurnal Pendidikan Matematika, 3(1), 1-10.
Sujuni, A., Jamal, M.A., \& Suyidno. (2014). Meningkatkan Hasil Belajar Siswa Melalui Model Pembelajaran Kooperatif Tipe Student Facilitator and Explaining. Berkala Ilmiah Pendidikan Fisika, 2(1), 31-42.

Widyawati, S. (2016). Eksperimentasi Model Pembelajaran Student Facilitator and Explaining (SFE) Terhadap Hasil Belajar ditinjau dari Kecerdasan Linguistik. Jurnal Pendidikan Matematika Al-jabar, 7(2) 267274.

Yanto, Y., \& Juwita, R. (2018). Penerapan Model Pembelajaran Kooperatif tipe Student Facilitator and Explaining Terhadap Hasil Belajar Matematika Siswa. Jurnal Pendidikan Matematika, 1(1), 53-60. 